\title{
Identification of LEF1 as a Susceptibility Locus for Kawasaki Disease in Patients Younger than 6 Months of Age
}

\author{
Hea-Ji Kim ${ }^{1}$, Sin Weon Yun ${ }^{2}$, Jeong Jin Yu ${ }^{3}$, Kyung Lim Yoon ${ }^{4}$, Kyung-Yil Lee ${ }^{5}$, Hong-Ryang Kil ${ }^{6}$, \\ Gi Beom Kim ${ }^{7}$, Myung-Ki Han ${ }^{8}$, Min Seob Song ${ }^{9}$, Hyoung Doo Lee ${ }^{10}$, Kee Soo Ha ${ }^{11}$, Sejung Sohn ${ }^{12}$, \\ Ryota Ebata $^{13}$, Hiromichi Hamada ${ }^{14}$, Hiroyuki Suzuki ${ }^{15}$, Yoichiro Kamatani ${ }^{16}$, Michiaki Kubo ${ }^{17}$,

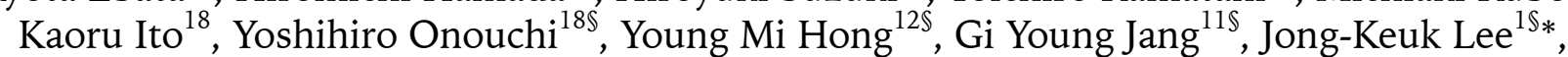 \\ The Korean Kawasaki Disease Genetics Consortium
}

\begin{abstract}
${ }^{1}$ Asan Institute for Life Sciences, University of Ulsan College of Medicine, Seoul 05505, Korea, ${ }^{2}$ Department of Pediatrics, Chung-Ang University Hospital, Seoul 06973, Korea, ${ }^{3}$ Department of Pediatrics, Asan Medical Center, University of Ulsan College of Medicine, Seoul 05505, Korea, ${ }^{4}$ Department of Pediatrics, Kyung Hee University Hospital at Gangdong, Seoul 05278, Korea, ${ }^{5}$ Department of Pediatrics, Daejeon St. Mary's Hospital, College of Medicine, The Catholic University of Korea, Daejeon 34943 Korea, ${ }^{6}$ Department of Pediatrics, Chungnam National University Hospital, Daejeon 35015, Korea, ${ }^{7}$ Department of Pediatrics, Seoul National University Children's Hospital, Seoul 03080, Korea, ${ }^{8}$ Department of Pediatrics, Gangneung Asan Hospital, University of Ulsan College of Medicine, Gangneung 25440, Korea, ${ }^{9}$ Department of Pediatrics, Inje University Busan Paik Hospital, Busan 47392, Korea, ${ }^{10}$ Department of Pediatrics, Pusan National University Hospital, Busan 49241, Korea, ${ }^{11}$ Department of Pediatrics, Korea University Ansan Hospital, Ansan 15355, Korea, ${ }^{12}$ Department of Pediatrics, Ewha Womans University Hospital, Seoul 07985, Korea, ${ }^{13}$ Department of Pediatrics, Chiba-University Graduate School of Medicine, Chiba 260-8670, Japan, ${ }^{14}$ Department of Pediatrics, Tokyo Women's Medical University Yachivo Medical Center, Yachivo 276-8524, Japan, ${ }^{15}$ Department of Pediatrics, Wakayama Medical University, Wakayama 641-8509, Japan, ${ }^{16}$ Laboratory for Statistical Analysis, RIKEN Center for Integrative Medical Sciences, Yokohama 230-0045, Japan, ${ }^{17}$ Laboratory for Genotyping Development, RIKEN Center for Integrative Medical Sciences, Yokohama 230-0045, Japan, ${ }^{18}$ Laboratory for Cardiovascular Diseases,
\end{abstract} RIKEN Center for Integrative Medical Sciences, Yokohama 230-0045, Japan

\begin{abstract}
Kawasaki disease (KD) is an acute febrile vasculitis predominately affecting infants and children. The dominant incidence age of KD is from 6 months to 5 years of age, and the incidence is unusual in those younger than 6 months and older than 5 years of age. We tried to identify genetic variants specifically associated with KD in patients younger than 6 months or older than 5 years of age. We performed an age-stratified genome-wide association study using the Illumina HumanOmni1-Quad BeadChip data (296 cases vs. 1,000 controls) and a replication study (1,360 cases vs. 3,553 controls) in the Korean population. Among 26 candidate single nucleotide polymorphisms (SNPs) tested in replication study, only a rare nonsynonymous SNP (rs4365796: c.1106C > T, p.Thr369Met) in the lymphoid enhancer binding factor 1 (LEF1) gene was very significantly associated with KD in patients younger than 6 months of age (odds ratio [OR], 3.07; $\mathrm{p}_{\text {combined }}=1.10 \times 10^{-5}$ ), whereas no association of the same SNP was observed in any other age group of KD patients. The same SNP ( $r s 4365796)$ in the LEF1 gene showed the same direction of risk effect in Japanese KD patients younger than 6 months of age, although the effect was not statistically significant $(\mathrm{OR}, 1.42 ; \mathrm{p}=0.397)$. This result indicates that the $L E F 1$ gene may play an important role as a susceptibility gene specifically affecting KD patients younger than 6 months of age.
\end{abstract}

Keywords: genome-wide association study, Kawasaki disease, lymphoid enhancer binding factor1 (LEF1), single nucleotide polymorphism 


\section{Introduction}

Kawasaki disease (KD) is an acute, self-limited vasculitis that predominantly occurs in children between the ages of 6 months and 5 years old. Approximately half of all $\mathrm{KD}$ patients are between 6 months to 2 years of age, which is the peak incidence age of $\mathrm{KD}[1,2]$. The etiology of $\mathrm{KD}$ is not known, and it has no specific diagnostic test. As such, $\mathrm{KD}$ diagnosis is based solely on six clinical symptoms: prolonged fever, bilateral conjunctival injection, erythema of the oral mucosa, lips, and tongue, polymorphous rash, erythema of the palms and soles, and cervical lymphadenopathy [3]. Complete KD is diagnosed when patients have at least five of the above six clinical symptoms, and incomplete $\mathrm{KD}$ is diagnosed when patients have less than four of the six clinical symptoms. The standard treatment of $\mathrm{KD}$ is a highdose intravenous immunoglobulin (IVIG), which is derived from pooled plasma of healthy donors, reducing the duration of fever and the incidence of coronary artery abnormalities $[4,5]$.

$\mathrm{KD}$ is considered an abnormal immunological reaction to an infection or unknown immunological triggers in genetically susceptible individuals $[6,7]$. B cell-related genes including $B L K, C D 40$, and FCGR2A were also identified as $\mathrm{KD}$ susceptibility genes by genome-wide association studies (GWAS) [8-10]. In particular, a reduced level of BLK expression in blood $\mathrm{B}$ cells may be a crucial reason for dysfunction of $\mathrm{B}$ cells and a pathogenesis of $\mathrm{KD}[10,11]$. Our previous study identified that a risk allele in FCGR2A was only susceptible for $\mathrm{KD}$ patients younger than 1 year of age, whereas the $\mathrm{KD}$ susceptible allele in $B L K$ affected all ages of $\mathrm{KD}$ patients, except those older than 5 years of age. This result revealed a possibility that there are other genetic variants affecting specific age subgroups of $\mathrm{KD}$ patients. In this study, to further identify age-specific susceptibility genes of KD in KD patients younger than 6 months or older than 5 years of age, we performed an age-stratified GWAS and a replication study and identified lymphoid enhancer binding factor 1 ( $L E F 1)$ as a KD susceptibility gene specifically affecting $\mathrm{KD}$ patients younger than 6 months of age.

\section{Methods}

\section{Study subjects and genotype data}

$\mathrm{KD}$ patients in this study were collected from 10 hospitals in Korea. The diagnosis of all KD patients was determined by the diagnostic criteria of the American Heart Association $[12,13]$. All laboratory test data were performed before the initial IVIG treatment, including white blood cell count, neutrophil count, platelet count, erythrocyte sedimentation rate (ESR), hemoglobin ( $\mathrm{Hb}), \mathrm{C}$-reactive protein (CRP), aspartate aminotransferase (AST), alanine aminotransferase (ALT), and total protein. A total of 1,699 $\mathrm{KD}$ patients in Korea were used in this study. Of them, $118 \mathrm{KD}$ patients were younger than 6 months of age and $231 \mathrm{KD}$ patients were older than 5 years of age. A total of 4,553 controls with no history of $\mathrm{KD}$ were obtained from the adult health cohort of the general population in Korea, which included 1,000 controls used in the initial GWAS and 3,500 controls used in the replication study. The GWAS was initially performed using our previous Illumina HumanOmni1-Quad BeadChip data (296 KD patients and 1,000 healthy controls) [14]. From the age-stratified GWAS analysis (19 cases; younger than 6 months of age KD patients and 45 cases; older than 5 years of age KD patients), a total of 12 single nucleotide polymorphisms (SNPs) and 14 SNPs were chosen as agespecific KD susceptibility loci for patients younger than 6 months and older than 5 years of age, respectively. Genotyping for the replication study in the 1,403 KD patients, including $99 \mathrm{KD}$ patients younger than 6 months and 186 $\mathrm{KD}$ patients older than 5 years of age, were performed using TaqMan assays and analyzed using an Applied Biosystems 7900HT Fast Real-Time PCR system (Thermo Fisher Scientific, Waltham, MA, USA). The genotypes of the control subjects in Korea were provided by the Biobank for Health Sciences at the Center for Genome Sciences in Cheongwon, Korea. The second replication study using a Japanese cohort was comprised of $1,306 \mathrm{KD}$ cases, including $120 \mathrm{KD}$ cases younger than 6 months of age, and 6,893 controls. Genotype data of the Japanese cohort was generated using the Illumina HumanOmniExpressExome BeadChip (Illumina, San Diego, CA, USA). Informed consent was obtained from the parents of all $\mathrm{KD}$ patients in this study.

\section{Statistical analysis}

Statistical analyses for the genetic associations and meta-analysis of the SNPs were performed using PLINK (ver. 1.07) [15]. To test the association with $\mathrm{KD}$, we performed the chi-square test to compare allele and genotype frequencies between cases and controls. To analyze the significance of differences in the distribution of variables of clinical characteristics in each genotype group, we used SPSS ver. 18 (SPSS Inc., Chicago, IL, USA). The Kolmogorov-Smirnov test was used to test for normality of the continuous variables. The continuous variables with a non-normal distribution were described by median and interquartile range. The Mann-Whitney U test was used in the continuous variables and the chi-square test was used in the categorical variables to contrast the genotype groups depending on the distribution of the data. The functional prediction of nonsynonymous SNP (rs4365796) was performed by PolyPhen and SIFT programs. 


\section{Results}

\section{Identification of LEF1 as a KD susceptibility gene specifically associated with KD in patients younger than 6 months of age.}

To identify the genetic variants affecting two extreme age subgroups of KD patients (younger than 6 months and older than 5 years of age), we performed an age-stratified GWAS using $19 \mathrm{KD}$ cases younger than 6 months or $45 \mathrm{KD}$ cases older than 5 years of age, respectively, compared to 1,000 controls. A total of 12 SNPs for patients younger than 6 months and 14 SNPs for those older than 5 years of age were chosen for the replication study on the basis of our arbitrary threshold ( $\mathrm{p}<1 \times 10^{-4}$ and genes related to immune functions) for each subgroup. Among 26 candidate SNPs tested in the replication study (Supplementary Tables 1 and 2), only a nonsynonymous SNP (rs4365796: c.1106C $>\mathrm{T}$, p.Thr369Met) in the LEF1 gene was validated in Korean $\mathrm{KD}$ patients younger than 6 months of age (odds ratio [OR], 5.92; $\mathrm{p}=0.000268$ in GWAS and OR, 2.60; $\mathrm{p}=0.00126$ in the replication study) (Table 1). The combined analysis of the Korean GWAS and replication for LEF1 SNP (rs4365796) showed very significant association with $\mathrm{KD}$ in patients younger than 6 months of age ( 118 cases vs. 4,553 controls; OR, 3.07; p combined $=1.10 \times 10^{-5}$ ), whereas no association of the same SNP was observed in any other age group of $\mathrm{KD}$ patients (Fig. 1, Supplementary Table 3). To further validate our findings in another population, we also performed a replication study in the Japanese cohort comprised of 1,306 KD cases and 6,893 controls. The SNP rs4365796 in the LEF1 gene showed the same direction of risk effect in Japanese KD patients younger than 6 months of age, although the effect was statistically not significant (OR, 1.42; $\mathrm{p}=$ 0.397) (Table 1). In a meta-analysis of Korean and Japanese data, a significant association was observed in $\mathrm{KD}$ patients younger than 6 months of age (OR, 2.50; $\left.\mathrm{p}=5.01 \times 10^{-5}\right)$, whereas no association was detected in $\mathrm{KD}$ patients older than 6 months of age (OR, 1.10; $\mathrm{p}=0.342)$ (Table 1). This result indicates that the $L E F 1$ gene is a novel susceptibility gene specifically affecting KD patients younger than 6 months of age.

To determine the effect of the LEF1 risk allele on clinical features of $\mathrm{KD}$ patients, we examined the clinical data classified by the LEF1 genotypes (rs4365796, risk allele: T)

Table 1. Age-stratified association results for LEF1 (rs4365796; risk allele: T) in Korean and Japanese populations

\begin{tabular}{|c|c|c|c|c|c|c|c|c|c|}
\hline \multirow[b]{2}{*}{ Country } & \multirow[b]{2}{*}{ Collection } & \multicolumn{4}{|c|}{ KD (age $\leq 0.5$ y) } & \multicolumn{4}{|c|}{ KD (age >0.5 y) } \\
\hline & & $\begin{array}{c}\text { No. } \\
\text { (case/control) }\end{array}$ & $\begin{array}{c}\text { RAF } \\
\text { (case/control) }\end{array}$ & $\begin{array}{c}\text { OR } \\
(95 \% \mathrm{Cl})\end{array}$ & p-value & $\begin{array}{c}\text { No. } \\
\text { (case/control) }\end{array}$ & $\begin{array}{c}\text { RAF } \\
\text { (case/control) }\end{array}$ & $\begin{array}{c}\text { OR } \\
(95 \% \quad \mathrm{Cl})\end{array}$ & p-value \\
\hline \multirow[t]{3}{*}{ Korea } & GWAS & $19 / 1,000$ & $0.105 / 0.020$ & $5.92(2.00-17.48)$ & $2.68 \times 10^{-4}$ & $277 / 1,000$ & $0.032 / 0.020$ & $1.69(0.96-2.98)$ & 0.067 \\
\hline & Replication & $99 / 3,553$ & $0.061 / 0.024$ & $2.60(1.42-4.75)$ & $1.26 \times 10^{-3}$ & $1,261 / 3,553$ & $0.025 / 0.024$ & $1.05(0.78-1.40)$ & 0.744 \\
\hline & Combined & $118 / 4,553$ & $0.068 / 0.023$ & $3.07(1.81-5.19)$ & $1.10 \times 10^{-5}$ & $1,538 / 4,553$ & $0.026 / 0.023$ & $1.15(0.89-1.50)$ & 0.275 \\
\hline Japan & Replication & $120 / 6,893$ & $0.025 / 0.018$ & $1.42(0.63-3.23)$ & 0.397 & $1,186 / 6,893$ & $0.018 / 0.018$ & $1.03(0.74-1.42)$ & 0.884 \\
\hline Meta & $\begin{array}{c}\text { Korea }+ \\
\text { Japan }\end{array}$ & $238 / 11,446$ & & $2.50(1.61-3.90)$ & $5.01 \times 10^{-5}$ & $2,724 / 11,446$ & & $1.10(0.9-1.35)$ & 0.342 \\
\hline
\end{tabular}

A meta-analysis was performed using 2 patient populations (Korea-combined and Japan-replication) with 2,962 cases of KD and 11,446 control subjects.

These statistical values are for the allelic model, and significant $p$-values $(p<0.05)$ are shown in bold

$\mathrm{KD}$, Kawasaki disease; RAF, risk allele frequency; OR, odds ratio; $95 \% \mathrm{Cl}, 95 \%$ confidence interval; GWAS, genome-wide association studies.

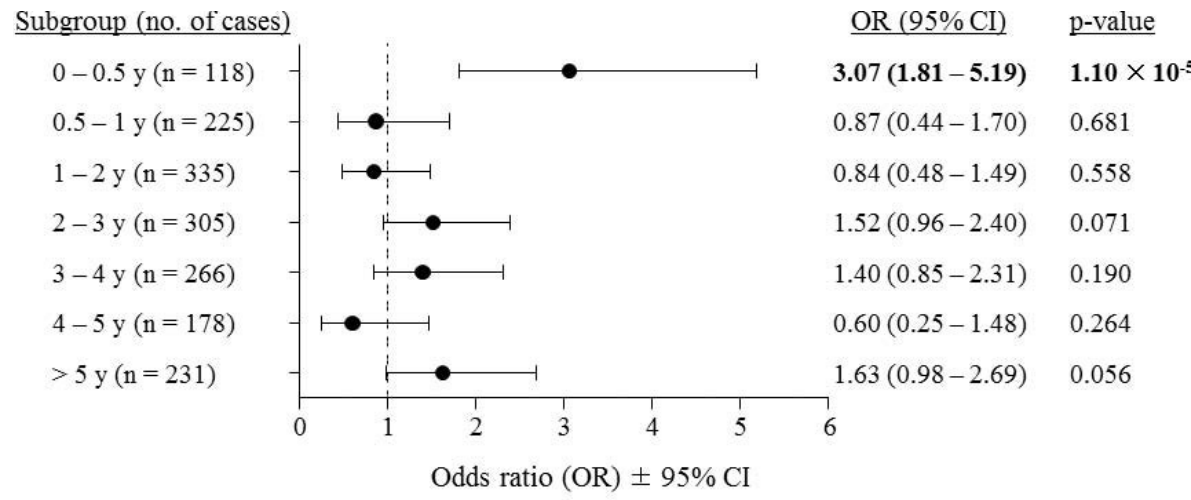

Fig. 1. Odds ratios (ORs) and confidence intervals $(\mathrm{Cls})$ of the LEF1 (rs4365796) association with Kawasaki disease (KD) according to age of Korean KD patients (total number of KD patients, 1,658). Each horizontal bar is a $95 \% \mathrm{Cl}$. A total of 4,553 controls were used in the genetic association analysis for each age subgroup of KD patients. Significant $\mathrm{p}$ values $(p<0.05)$ are shown in bold. 
in 1,656 Korean KD patients (number of genotype: $\mathrm{CC}=$ $1,559, \mathrm{CT} / \mathrm{TT}=96 / 1$ ). When we investigated the effect of genotype of the LEF1 risk allele in two $\mathrm{KD}$ subgroups (younger than 6 months and older than 6 months of age), the risk allele did not show any significant effect on any clinical variables in $\mathrm{KD}$ patients with one exception; the risk genotypes (either CT or TT) of the LEF1 gene (rs4365796) had slightly increased CRP levels (median, $8.48 \mathrm{mg} / \mathrm{L} ; \mathrm{p}=0.032$ ) in $\mathrm{KD}$ patients older than 6 months of age compared to the non-risk genotype (CC) of the LEF1 gene (median, $6.50 \mathrm{mg} / \mathrm{L}$ ) (Supplementary Table 4).

\section{Discussion}

The incidence of KD in patients younger than 6 months and older than 5 years of age was comparatively lower than other age groups. The peak incidence of $\mathrm{KD}$ was in the age group between 6 months and 2 years of age. KD has no diagnostic test and the diagnosis depends on clinical symptoms. In particular, KD patients younger than 6 months of age can be difficult to diagnose because they show fewer clinical symptoms, called incomplete $\mathrm{KD}$, which leads to delayed diagnosis or misdiagnosis in infants. Consequently, cardiac complications are more common in $\mathrm{KD}$ patients younger than 6 months than in older children [16-18]. Therefore, early and accurate diagnosis of infantile $\mathrm{KD}$ is important to reduce the risk of cardiac complications. In this study, we analyzed GWAS data of patients younger than 6 months and older than 5 years of age to identify new risk loci for $\mathrm{KD}$ susceptibility in these age groups. We identified a new KD susceptibility locus in the LEF1 gene (rs4365796: c. $1106 \mathrm{C}>\mathrm{T}$, p.Thr369Met) on chromosome 4 . The associated amino acid-altering SNP (rs4365796) in the LEF1 gene had an unusually strong effect size, a 3.07-fold increased risk for incidence of KD, in Korean $\mathrm{KD}$ patients younger than 6 months of age. This result indicates that the LEF1 gene plays a crucial role in the pathogenesis of $\mathrm{KD}$ in very young children and this amino acid-altering variant can be used as a candidate marker to identify high risk KD patients in infant patients in a clinical setting.

The LEF1 gene encodes a transcription factor that is expressed in developing $B$ and $T$ cells and at multiple sites of organogenesis during embryonic development [19-21]. LEF1 is a central mediator of the Wnt signaling pathway through recruiting $\beta$-catenin and plays crucial roles during development, including normal hematopoiesis [22, 23]. Abnormal protein expression of $L E F 1$ has been detected in chronic lymphocytic leukemia (CLL) cells and monoclonal B-cell lymphocytosis, indicating that $L E F 1$ plays an early role in B-cell development and CLL leukemogenesis [24]. Transplantation of LEF1-transduced bone marrow also developed acute myeloid leukemia and B-precursor acute lymphoblastic leukemia in mouse models [25]. Additionally, LEF1 contributes to the survival and proliferation of pro-B cells during early B cell development [26]. GWAS also identified the LEF1 gene as a susceptibility locus for systemic lupus erythematosus and CLL [27-29]. These previous results suggest that the dysfunction of the LEF1 gene is involved in early B lymphocyte development, which is involved in the pathogenesis of $\mathrm{KD}$. In our study, we found that a nonsynonymous SNP (rs4365796: c.1106C $>$ T, p.Thr369Met) was significantly associated with $\mathrm{KD}$ in patients younger than 6 months of age. This SNP was predicted as probably damaging and deleterious by PolyPhen and SIFT, respectively, suggesting that this amino acidaltering variant can change the biological functions of LEF1 protein, probably during the early development of B cells.

Although we found that a nonsynonymous SNP (rs4365796: c.1106C > T, p.Thr369Met) in the LEF1 gene is significantly associated with $\mathrm{KD}$ in Korean patients younger than 6 months of age, the biological role of the LEF1 variant is still unknown. Therefore, we should investigate how the amino acid-altering $L E F 1$ variant specifically affects the immune response in infants and subsequently the potential mechanism of LEF1-mediated pathogenesis in KD. Additionally, the significantly associated SNP (rs4365796) in the LEF1 gene in Korean KD patients was not replicated in the Japanese samples, although the same direction of risk effect was detected (Table 1). As shown in Table 1, the risk allele of the $L E F 1$ gene is a rare variant with lower allele frequency in the Japanese population (risk allele frequency $=0.023$ in Korean vs. 0.018 in Japanese control samples). Furthermore, the portions of KD patients younger than 6 months of age was higher in Japan (9.19\% in Japan vs. $7.13 \%$ in Korea) (Table 1), suggesting that Korean $\mathrm{KD}$ patients younger than 6 months of age are a genetically enriched and more homogeneous case population. A previous study also reported that the Japanese population has a higher incidence of $\mathrm{KD}$ in patients younger than 6 months of age compared to the Korean population ( $11.2 \%$ in Japanese KD patients vs. $7.7 \%$ in Korean $\mathrm{KD}$ patients) [30]. Therefore, we assume that no replication of the $L E F 1$ gene in the Japanese samples may be due to the lower frequency of the risk allele in the LEF1 gene and/or higher $\mathrm{KD}$ incidence in those younger than 6 months of age compared to the Korean population. Conversely, another limitation of our study is the low statistical power due to the small sample size resulting from the selection of a rare variant with an allele frequency less than $2.5 \%$ and of age subgroups of KD patients, particularly younger than 6 months of age (less than $10 \%$ of total KD cases). Therefore, to support our findings, further replication studies are necessary in more independent sample sets with larger 
sample size.

In conclusion, we identified that a nonsynonymous SNP (rs4365796: c.1106C > T, p.Thr369Met) in the LEF1 gene is significantly associated with KD in children younger than 6 months of age. This amino acid-altering variant in the LEF1 gene will be useful to identify high risk KD patients younger than 6 months of age because this SNP had a strong effect size (OR, 3.07). This result will provide new insight into the pathogenesis of the KD in infants.

ORCID: Hea-Ji Kim: https://orcid.org/0000-0002-6285-1 121; Sin Weon Yun: https://orcid.org/0000-0001-8947-70 3X; Jeong Jin Yu: https://orcid.org/0000-0003-1601-3685; Kyung Lim Yoon: https://orcid.org/0000-0003-4734-900X; Kyung-Yil Lee: https://orcid.org/0000-0001-6510-1580; Hong-Ryang Kil: https://orcid.org/0000-0003-4925-8240; Gi Beom Kim: https://orcid.org/0000-0002-7880-280X; Myung-Ki Han: https://orcid.org/0000-0003-1817-8088; Min Seob Song: https://orcid.org/0000-0003-3426-6803; Hyoung Doo Lee: https://orcid.org/0000-0002-6125-187 X; Kee Soo Ha: https://orcid.org/0000-0001-6753-5411; Sejung Sohn: https://orcid.org/0000-0001-9960-7774; Ryota Ebata: https://orcid.org/0000-0001-8471-1042; Hiromichi Hamada: https://orcid.org/0000-0002-8990-52 65; Hiroyuki Suzuki: https://orcid.org/0000-0003-0420-91 46; Yoichiro Kamatani: https://orcid.org/0000-0001-87485597; Michiaki Kubo: https://orcid.org/0000-0002-0095-2 322; Kaoru Ito: https://orcid.org/0000-0003-1843-773X; Yoshihiro Onouchi: https://orcid.org/0000-0002-9272-26 89; Young Mi Hong: https://orcid.org/0000-0002-6600-78 76; Gi Young Jang: https://orcid.org/0000-0002-4831-118 8; Jong-Keuk Lee: 0000-0003-1125-4017

\section{Authors' contribution}

Conceptualization: JKL

Data curation: SWY, JJY, KLY, KYL, HRK, GBK, MKH, MSS, HDL, KSH, SS, RE, HH, HS, YK, MK, KI, YO, YMH, GYJ

Formal analysis: HJK

Funding acquisition: JKL

Methodology: HJK

Validation: YO

Supervision: JKL, YMH, GYJ, YO

Writing - original draft: HJK

Writing - review \& editing: JKL, YMH, GYJ, YO

\section{Acknowledgments}

We thank all the patients with Kawasaki disease and their families for participating in this study. This work was supported by a grant from the Ministry of Health \& Welfare of the Republic of Korea (HI15C1575).

\section{Supplementary materials}

Supplementary data including four tables can be found with this article online at https://doi.org/10.5808/GI. 2018.16.2.36

\section{References}

1. Melish ME. Kawasaki syndrome. Pediatr Rev 1996;17:153-162.

2. Rowley AH, Shulman ST. Kawasaki syndrome. Pediatr Clin North Am 1999;46:313-329.

3. Burns JC, Glode MP. Kawasaki syndrome. Lancet 2004;364: 533-544.

4. Wu MH, Chen HC, Yeh SJ, Lin MT, Huang SC, Huang SK. Prevalence and the long-term coronary risks of patients with Kawasaki disease in a general population $<40$ years: a national database study. Circ Cardiovasc Qual Outcomes 2012;5: 566-570.

5. Gürcan HM, Keskin DB, Ahmed AR. Information for healthcare providers on general features of IGIV with emphasis on differences between commercially available products. Autoimmun Rev 2010;9:553-559.

6. Newburger JW, Fulton DR. Kawasaki disease. Curr Opin Pediatr 2004;16:508-514

7. Lee KY, Han JW, Lee JS. Kawasaki disease may be a hyperimmune reaction of genetically susceptible children to variants of normal environmental flora. Med Hypotheses 2007; 69:642-651.

8. Onouchi Y, Ozaki K, Burns JC, Shimizu C, Terai M, Hamada H, et al. A genome-wide association study identifies three new risk loci for Kawasaki disease. Nat Genet 2012;44:517-521.

9. Lee YC, Kuo HC, Chang JS, Chang LY, Huang LM, Chen MR, et al. Two new susceptibility loci for Kawasaki disease identified through genome-wide association analysis. Nat Genet 2012;44:522-525.

10. Khor CC, Davila S, Breunis WB, Lee YC, Shimizu C, Wright $\mathrm{VJ}$, et al. Genome-wide association study identifies FCGR2A as a susceptibility locus for Kawasaki disease. Nat Genet 2011;43:1241-1246.

11. Chang CJ, Kuo HC, Chang JS, Lee JK, Tsai FJ, Khor CC, et al. Replication and meta-analysis of GWAS identified susceptibility loci in Kawasaki disease confirm the importance of B lymphoid tyrosine kinase (BLK) in disease susceptibility. PLoS One 2013;8:e72037.

12. Newburger JW, Takahashi M, Gerber MA, Gewitz MH, Tani LY, Burns JC, et al. Diagnosis, treatment, and long-term management of Kawasaki disease: a statement for health professionals from the Committee on Rheumatic Fever, Endocarditis and Kawasaki Disease, Council on Cardiovascular Disease in the Young, American Heart Association. Circulation 2004;110:2747-2771.

13. McCrindle BW, Rowley AH, Newburger JW, Burns JC, Bolger $\mathrm{AF}$, Gewitz M, et al. Diagnosis, treatment, and long-term management of Kawasaki disease: a scientific statement for health 
professionals from the American Heart Association. Circulation 2017;135:e927-e999.

14. Kim JJ, Yun SW, Yu JJ, Yoon KL, Lee KY, Kil HR, et al. A genome-wide association analysis identifies NMNAT2 and HCP5 as susceptibility loci for Kawasaki disease. J Hum Genet 2017;62:1023-1029.

15. Purcell S, Neale B, Todd-Brown K, Thomas L, Ferreira MA, Bender D, et al. PLINK: a tool set for whole-genome association and population-based linkage analyses. Am J Hum Genet 2007;81:559-575.

16. No SJ, Kim DO, Choi KM, Eun LY. Do predictors of incomplete Kawasaki disease exist for infants? Pediatr Cardiol 2013;34: 286-290.

17. Park YW, Han JW, Park IS, Kim CH, Cha SH, Ma JS, et al. Epidemiologic study of Kawasaki disease in 6 months old and younger infants. Korean J Pediatr 2008;51:1320-1323.

18. Burns JC, Wiggins JW Jr, Toews WH, Newburger JW, Leung DY, Wilson $\mathrm{H}$, et al. Clinical spectrum of Kawasaki disease in infants younger than 6 months of age. J Pediatr 1986;109: 759-763.

19. Oosterwegel $M$, van de Wetering M, Dooijes D, Klomp L, Winoto A, Georgopoulos K, et al. Cloning of murine TCF-1, a $\mathrm{T}$ cell-specific transcription factor interacting with functional motifs in the CD3-epsilon and T cell receptor alpha enhancers. J Exp Med 1991;173:1133-1142.

20. Travis A, Amsterdam A, Belanger C, Grosschedl R. LEF-1, a gene encoding a lymphoid-specific protein with an HMG domain, regulates $\mathrm{T}$-cell receptor alpha enhancer function [corrected]. Genes Dev 1991;5:880-894.

21. van Genderen C, Okamura RM, Fariñas I, Quo RG, Parslow TG, Bruhn L, et al. Development of several organs that require inductive epithelial-mesenchymal interactions is impaired in LEF-1-deficient mice. Genes Dev 1994;8:2691-2703.
22. Reya T, Duncan AW, Ailles L, Domen J, Scherer DC, Willert K, et al. A role for Wnt signalling in self-renewal of haematopoietic stem cells. Nature 2003;423:409-414.

23. Arce L, Yokoyama NN, Waterman ML. Diversity of LEF/TCF action in development and disease. Oncogene 2006;25:7492-7504.

24. Gutierrez A, Jr., Tschumper RC, Wu X, Shanafelt TD, EckelPassow J, Huddleston PM 3rd, et al. LEF-1 is a prosurvival factor in chronic lymphocytic leukemia and is expressed in the preleukemic state of monoclonal B-cell lymphocytosis. Blood 2010;116:2975-2983.

25. Petropoulos K, Arseni N, Schessl C, Stadler CR, Rawat VP, Deshpande AJ, et al. A novel role for Lef-1, a central transcription mediator of Wnt signaling, in leukemogenesis. J Exp Med 2008;205:515-522.

26. Reya T, O'Riordan M, Okamura R, Devaney E, Willert K, Nusse R, et al. Wnt signaling regulates B lymphocyte proliferation through a LEF-1 dependent mechanism. Immunity 2000;13:15-24.

27. Okada Y, Shimane K, Kochi Y, Tahira T, Suzuki A, Higasa K, et al. A genome-wide association study identified AFF1 as a susceptibility locus for systemic lupus eyrthematosus in Japanese. PLoS Genet 2012;8:e1002455.

28. Sabatti C, Service SK, Hartikainen AL, Pouta A, Ripatti S, Brodsky J, et al. Genome-wide association analysis of metabolic traits in a birth cohort from a founder population. Nat Genet 2009;41:35-46.

29. Berndt SI, Skibola CF, Joseph V, Camp NJ, Nieters A, Wang Z, et al. Genome-wide association study identifies multiple risk loci for chronic lymphocytic leukemia. Nat Genet 2013;45: 868-876.

30. Yeom JS, Woo HO, Park JS, Park ES, Seo JH, Youn HS. Kawasaki disease in infants. Korean J Pediatr 2013;56:377-382. 


\title{
SUPPLEMENTARY INFORMATION
}

\author{
Identification of LEF1 as a Susceptibility Locus for Kawasaki \\ Disease in Patients Younger than 6 Months of Age
}

\begin{abstract}
Hea-Ji $\mathrm{Kim}^{1}$, Sin Weon Yun ${ }^{2}$, Jeong Jin $\mathrm{Yu}^{3}$, Kyung Lim Yoon ${ }_{9}^{4}$ Kyung-Yil Lee ${ }^{5}$, Hong-Ryang Kil ${ }^{6}$, Gi Beom Kim ${ }^{7}$, Myung-Ki Han ${ }^{8}$, Min Seob Song, Hyoung Doo Lee ${ }^{10}$, Kee Soo Ha ${ }^{11}$, Sejung Sohn ${ }^{12}$, Ryota Ebata ${ }^{13}$ Hiromichi Hamada ${ }^{14}$ Hiroyuki Suzuki ${ }^{15}$, Yoichiro Kamatani ${ }^{16}$, Michiaki Kubo ${ }^{1 \%}$, Kaoru Ito ${ }^{18}$, Yoshihiro Onouchi ${ }^{18 \S}$, Young Mi Hong ${ }^{12 \S}$, Gi Young Jang ${ }^{11 \S}$, Jong-Keuk Lee ${ }^{1 \S *}$, The Korean Kawasaki Disease Genetics Consortium
\end{abstract}

${ }^{1}$ Asan Institute for Life Sciences, University of Ulsan College of Medicine, Seoul 05505, Korea, ${ }^{2}$ Department of Pediatrics, Chung-Ang University Hospital, Seoul 06973, Korea, ${ }^{3}$ Department of Pediatrics, Asan Medical Center, University of Ulsan College of Medicine, Seoul 05505, Korea, ${ }^{4}$ Department of Pediatrics, Kyung Hee University Hospital at Gangdong, Seoul 05278, Korea, ${ }^{5}$ Department of Pediatrics, Daejeon St. Mary's Hospital, College of Medicine, The Catholic University of Korea, Daejeon 34943, Korea, ${ }^{6}$ Department of Pediatrics, Chungnam National University Hospital, Daejeon 35015, Korea, ${ }^{7}$ Department of Pediatrics, Seoul National University Children's Hospital, Seoul 03080, Korea, ${ }^{8}$ Department of Pediatrics, Gangneung Asan Hospital, University of Ulsan College of Medicine, Gangneung 25440, Korea, ${ }^{9}$ Department of Pediatrics, Inje University Busan Paik Hospital, Busan 47392, Korea, ${ }^{10}$ Department of Pediatrics, Pusan National University Hospital, Busan 49241, Korea, ${ }^{11}$ Department of Pediatrics, Korea University Ansan Hospital, Ansan 15355, Korea,

${ }^{12}$ Department of Pediatrics, Ewha Womans University Hospital, Seoul 07985, Korea, ${ }^{13}$ Department of Pediatrics, Chiba-University Graduate School of Medicine, Chiba 260-8670, Japan, ${ }^{14}$ Department of Pediatrics, Tokyo Women's Medical University Yachivo Medical Center, Yachivo 276-8524, Japan, ${ }^{15}$ Department of Pediatrics, Wakayama Medical University, Wakayama 641-8509, Japan, ${ }^{16}$ Laboratory for Statistical Analysis, RIKEN Center for Integrative Medical Sciences, Yokohama 230-0045, Japan, ${ }^{17}$ Laboratory for Genotyping Development, RIKEN Center for Integrative Medical Sciences, Yokohama 230-0045, Japan, ${ }^{18}$ Laboratory for Cardiovascular Diseases, RIKEN Center for Integrative Medical Sciences, Yokohama 230-0045, Japan 
Supplementary Table 1. Association results of 12 candidate SNPs selected from KD patients younger than 6 months of age

\begin{tabular}{|c|c|c|c|c|c|c|c|c|c|c|c|c|}
\hline \multirow[t]{2}{*}{ Locus } & \multirow[t]{2}{*}{ Chr } & \multirow[t]{2}{*}{ SNP } & \multirow[t]{2}{*}{ Risk allele } & \multirow[t]{2}{*}{ Collection } & \multicolumn{4}{|c|}{$\mathrm{KD}($ age $\leq 0.5 \mathrm{y})$ vs. Controls } & \multicolumn{4}{|c|}{$\mathrm{KD}$ (age $3<$ to $\leq 5 \mathrm{y}$ ) vs. Controls } \\
\hline & & & & & $\begin{array}{c}\text { No. } \\
\text { (case/control) }\end{array}$ & $\begin{array}{c}\text { RAF } \\
\text { (case/control) }\end{array}$ & OR $(95 \% \mathrm{CI})$ & $\mathrm{p}$-value & $\begin{array}{c}\text { No. } \\
\text { (case/control) }\end{array}$ & $\begin{array}{c}\text { RAF } \\
\text { (case/control) }\end{array}$ & OR $(95 \% \mathrm{CI})$ & p-value \\
\hline CSF1 & 1 & rs333949 & $\mathrm{G}$ & $\begin{array}{l}\text { GWAS } \\
\text { Replication } \\
\text { Combined }\end{array}$ & $\begin{array}{l}19 / 1,000 \\
46 / 3,553 \\
65 / 4,553\end{array}$ & $\begin{array}{l}0.079 / 0.012 \\
0.012 / 0.010 \\
0.032 / 0.010\end{array}$ & $\begin{array}{c}7.36(2.11-25.66) \\
1.15(0.16-8.36) \\
3.16(1.14-8.73)\end{array}$ & $\begin{array}{c}2.45 \times 10^{-4} \\
0.891 \\
0.019\end{array}$ & $80 / 1,000$ & $0.013 / 0.012$ & $1.09(0.25-4.65)$ & 0.911 \\
\hline$C D 84$ & 1 & rs 1570707 & $\mathrm{~T}$ & $\begin{array}{l}\text { GWAS } \\
\text { Replication } \\
\text { Combined }\end{array}$ & $\begin{array}{l}19 / 1,000 \\
46 / 3,553 \\
65 / 4,553\end{array}$ & $\begin{array}{l}0.211 / 0.050 \\
0.058 / 0.065 \\
0.105 / 0.062\end{array}$ & $\begin{array}{c}5.12(2.29-11.46) \\
0.88(0.36-2.19) \\
1.78(0.99-3.18)\end{array}$ & $\begin{array}{c}1.04 \times 10^{-5} \\
0.789 \\
0.049\end{array}$ & $80 / 1,000$ & $0.071 / 0.050$ & $1.46(0.76-2.78)$ & 0.251 \\
\hline$I L 1 R N$ & 2 & rs 2902452 & A & $\begin{array}{l}\text { GWAS } \\
\text { Replication } \\
\text { Combined }\end{array}$ & $\begin{array}{l}19 / 1,000 \\
46 / 3,553 \\
65 / 4,553\end{array}$ & $\begin{array}{l}0.237 / 0.074 \\
0.089 / 0.074 \\
0.133 / 0.074\end{array}$ & $\begin{array}{l}3.91(1.82-8.42) \\
1.22(0.58-2.53) \\
1.91(1.14-3.21)\end{array}$ & $\begin{array}{c}1.76 \times 10^{-4} \\
0.601 \\
0.012\end{array}$ & $80 / 1,000$ & 0.0500 .074 & $0.66(0.32-1.38)$ & 0.268 \\
\hline CXCR4 & 2 & rs6716987 & $\mathrm{C}$ & $\begin{array}{l}\text { GWAS } \\
\text { Replication } \\
\text { Combined }\end{array}$ & $\begin{array}{l}19 / 1,000 \\
46 / 3,553 \\
65 / 4,553\end{array}$ & $\begin{array}{l}0.421 / 0.183 \\
0.152 / 0.175 \\
0.231 / 0.177\end{array}$ & $\begin{array}{l}3.25(1.69-6.24) \\
0.85(0.48-1.50) \\
1.40(0.93-2.11)\end{array}$ & $\begin{array}{c}1.95 \times 10^{-4} \\
0.568 \\
0.109\end{array}$ & $80 / 1,000$ & $0.194 / 0.183$ & $1.07(0.71-1.61)$ & 0.736 \\
\hline$L E F 1$ & 4 & rs4365796 & A & $\begin{array}{l}\text { GWAS } \\
\text { Replication } \\
\text { Combined }\end{array}$ & $\begin{array}{l}19 / 1,000 \\
46 / 3,553 \\
65 / 4,553\end{array}$ & $\begin{array}{l}0.105 / 0.020 \\
0.076 / 0.024 \\
0.085 / 0.023\end{array}$ & $\begin{array}{c}5.92(2.00-17.48) \\
3.32(1.51-7.28) \\
3.90(2.07-7.34)\end{array}$ & $\begin{array}{c}2.68 \times 10^{-4} \\
0.001 \\
5.58 \times 10^{-6}\end{array}$ & $80 / 1,000$ & $0.025 / 0.020$ & $1.29(0.45-3.65)$ & 0.632 \\
\hline$D E F B 1$ & 8 & rs 2738165 & $\mathrm{C}$ & $\begin{array}{l}\text { GWAS } \\
\text { Replication } \\
\text { Combined }\end{array}$ & $\begin{array}{l}19 / 1,000 \\
46 / 3,553 \\
65 / 4,553\end{array}$ & $\begin{array}{l}0.763 / 0.492 \\
0.522 / 0.498 \\
0.592 / 0.496\end{array}$ & $\begin{array}{l}3.33(1.57-7.08) \\
1.10(0.73-1.66) \\
1.48(1.04-2.10)\end{array}$ & $\begin{array}{c}9.07 \times 10^{-5} \\
0.644 \\
0.029\end{array}$ & $80 / 1,000$ & $0.494 / 0.492$ & $1.01(0.73-1.39)$ & 0.956 \\
\hline$S T 3 G A L 1$ & 8 & rs9643302 & $\mathrm{T}$ & $\begin{array}{l}\text { GWAS } \\
\text { Replication } \\
\text { Combined }\end{array}$ & $\begin{array}{l}19 / 1,000 \\
46 / 3,553 \\
65 / 4,553\end{array}$ & $\begin{array}{l}0.237 / 0.076 \\
0.043 / 0.074 \\
0.100 / 0.075\end{array}$ & $\begin{array}{l}3.77(1.75-8.12) \\
0.57(0.21-1.55) \\
1.38(0.77-2.46)\end{array}$ & $\begin{array}{c}2.71 \times 10^{-4} \\
0.263 \\
0.275\end{array}$ & $80 / 1,000$ & $0.081 / 0.076$ & $1.08(0.60-1.94)$ & 0.810 \\
\hline$P A X 5$ & 9 & rs 1536876 & A & $\begin{array}{l}\text { GWAS } \\
\text { Replication } \\
\text { Combined }\end{array}$ & $\begin{array}{l}19 / 1,000 \\
46 / 3,553 \\
65 / 4,553\end{array}$ & $\begin{array}{l}0.395 / 0.163 \\
0.198 / 0.175 \\
0.258 / 0.173\end{array}$ & $\begin{array}{l}3.35(1.73-6.49) \\
1.16(0.68-1.98) \\
1.67(1.11-2.50)\end{array}$ & $\begin{array}{c}1.50 \times 10^{-4} \\
0.587 \\
0.013\end{array}$ & $80 / 1,000$ & $0.206 / 0.163$ & $1.33(0.89-1.99)$ & 0.157 \\
\hline CCND2 & 12 & rs11063069 & G & $\begin{array}{l}\text { GWAS } \\
\text { Replication } \\
\text { Combined }\end{array}$ & $\begin{array}{l}19 / 1,000 \\
46 / 3,553 \\
65 / 4,553\end{array}$ & $\begin{array}{l}0.211 / 0.042 \\
0.078 / 0.050 \\
0.117 / 0.048\end{array}$ & $\begin{array}{c}6.08(2.71-13.67) \\
1.60(0.73-3.48) \\
2.61(1.51-4.52)\end{array}$ & $\begin{array}{c}7.16 \times 10^{-7} \\
0.234 \\
3.53 \times 10^{-4}\end{array}$ & $80 / 1,000$ & $0.063 / 0.042$ & $1.52(0.77-2.99)$ & 0.221 \\
\hline$B C L 11 B$ & 14 & rs 2693689 & A & $\begin{array}{l}\text { GWAS } \\
\text { Replication } \\
\text { Combined }\end{array}$ & $\begin{array}{l}19 / 1,000 \\
46 / 3,553 \\
65 / 4,553\end{array}$ & $\begin{array}{l}0.105 / 0.018 \\
0.000 / 0.015 \\
0.031 / 0.015\end{array}$ & $\begin{array}{c}6.61(2.22-19.62) \\
0 \\
2.07(0.75-5.67)\end{array}$ & $\begin{array}{c}9.16 \times 10^{-5} \\
0.245 \\
0.150\end{array}$ & $80 / 1,000$ & $0.006 / 0.018$ & $0.35(0.05-2.59)$ & 0.285 \\
\hline IL29 & 19 & rs 7247086 & $\mathrm{~T}$ & $\begin{array}{l}\text { GWAS } \\
\text { Replication } \\
\text { Combined }\end{array}$ & $\begin{array}{l}19 / 1,000 \\
46 / 3,553 \\
65 / 4,553\end{array}$ & $\begin{array}{l}0.105 / 0.022 \\
0.033 / 0.024 \\
0.054 / 0.024\end{array}$ & $\begin{array}{c}5.23(1.78-15.37) \\
1.36(0.43-4.34) \\
2.34(1.08-5.08)\end{array}$ & $\begin{array}{c}8.00 \times 10^{-4} \\
0.603 \\
0.026\end{array}$ & $80 / 1,000$ & $0.031 / 0.022$ & $1.43(0.56-3.67)$ & 0.450 \\
\hline FPR1 & 19 & rs11667868 & $\mathrm{A}$ & $\begin{array}{l}\text { GWAS } \\
\text { Replication } \\
\text { Combined } \\
\end{array}$ & $\begin{array}{l}19 / 1,000 \\
46 / 3,553 \\
65 / 4,553 \\
\end{array}$ & $\begin{array}{l}0.684 / 0.389 \\
0.369 / 0.392 \\
0.467 / 0.391\end{array}$ & $\begin{array}{l}3.40(1.71-6.78) \\
0.91(0.58-1.42) \\
1.37(0.95-1.95) \\
\end{array}$ & $\begin{array}{c}2.26 \times 10^{-4} \\
0.674 \\
0.087 \\
\end{array}$ & $80 / 1,000$ & $0.381 / 0.389$ & $0.97(0.69-1.35)$ & 0.847 \\
\hline
\end{tabular}

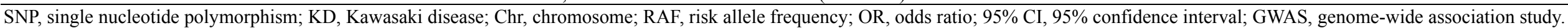


Supplementary Table 2. Association results of 14 candidate SNPs selected from KD patients older than 5 years of age

\begin{tabular}{|c|c|c|c|c|c|c|c|c|c|c|c|c|}
\hline \multirow[t]{2}{*}{ Locus } & \multirow[t]{2}{*}{ Chr } & \multirow[t]{2}{*}{ SNP } & \multirow[t]{2}{*}{ Risk allele } & \multirow[t]{2}{*}{ Collection } & \multicolumn{4}{|c|}{ KD (age $>5$ y) vs. Controls } & \multicolumn{4}{|c|}{$\mathrm{KD}($ age $\leq 5 \mathrm{y})$ vs. Controls } \\
\hline & & & & & $\begin{array}{c}\text { No. } \\
\text { (case/control) }\end{array}$ & $\begin{array}{c}\text { RAF } \\
\text { (case/control) }\end{array}$ & OR $(95 \% \mathrm{CI})$ & $\mathrm{p}$-value & $\begin{array}{c}\text { No. } \\
\text { (case/control) }\end{array}$ & $\begin{array}{c}\text { RAF } \\
\text { (case/control) }\end{array}$ & OR $(95 \% \mathrm{CI})$ & $\mathrm{p}$-value \\
\hline \multirow[t]{3}{*}{ SLAMF1 } & 1 & rs2295613 & $\mathrm{T}$ & GWAS & $45 / 1,000$ & $0.422 / 0.259$ & $2.09(1.36-3.21)$ & $6.08 \times 10^{-4}$ & $251 / 1,000$ & $0.285 / 0.259$ & $1.14(0.92-1.42)$ & 0.240 \\
\hline & & & & Replication & $48 / 3,553$ & $0.177 / 0.267$ & $0.59(0.35-1.00)$ & 0.048 & & & & \\
\hline & & & & Combined & $93 / 4,553$ & $0.296 / 0.265$ & $1.16(0.85-1.60)$ & 0.351 & & & & \\
\hline \multirow[t]{3}{*}{ IL28RA } & 1 & rs7552086 & A & GWAS & $45 / 1,000$ & $0.600 / 0.370$ & $2.55(1.66-3.93)$ & $1.09 \times 10^{-5}$ & $251 / 1,000$ & $0.376 / 0.370$ & $1.03(0.84-1.26)$ & 0.788 \\
\hline & & & & Replication & $48 / 3,553$ & $0.344 / 0.361$ & $0.93(0.61-1.42)$ & 0.732 & & & & \\
\hline & & & & Combined & $93 / 4,553$ & $0.468 / 0.363$ & $1.54(1.15-2.07)$ & 0.003 & & & & \\
\hline \multirow[t]{3}{*}{ INPP5D } & 2 & rs46663337 & G & GWAS & $45 / 1,000$ & $0.089 / 0.016$ & $6.00(2.68-13.43)$ & $7.93 \times 10^{-7}$ & $251 / 1,000$ & $0.022 / 0.016$ & $1.38(0.69-2.75)$ & 0.362 \\
\hline & & & & Replication & $48 / 3,553$ & $0.031 / 0.020$ & $1.57(0.49-5.02)$ & 0.442 & & & & \\
\hline & & & & Combined & $93 / 4,553$ & $0.059 / 0.019$ & $3.21(1.71-6.01)$ & $1.19 \times 10^{-4}$ & & & & \\
\hline \multirow[t]{3}{*}{$I R A K 2$} & 3 & rs2302862 & G & GWAS & $45 / 1,000$ & $0.289 / 0.143$ & $2.44(1.52-3.91)$ & $1.45 \times 10^{-4}$ & $251 / 1,000$ & $0.151 / 0.143$ & $1.07(0.81-1.41)$ & 0.633 \\
\hline & & & & Replication & $48 / 3,553$ & $0.135 / 0.145$ & $0.92(0.51-1.66)$ & 0.789 & & & & \\
\hline & & & & Combined & $93 / 4,553$ & $0.210 / 0.145$ & $1.57(1.10-2.24)$ & 0.013 & & & & \\
\hline \multirow[t]{2}{*}{ IL33 } & 9 & rs12349559 & $\mathrm{C}$ & GWAS & $45 / 1,000$ & $0.244 / 0.121$ & $2.36(1.43-3.89)$ & $5.24 \times 10^{-4}$ & $251 / 1,000$ & $0.112 / 0.121$ & $0.92(0.67-1.25)$ & 0.580 \\
\hline & & & & Replication & $48 / 3,553$ & $0.056 / 0.112$ & $0.47(0.19-1.16)$ & 0.093 & & & & \\
\hline \multirow[t]{3}{*}{ NFIL3 } & 9 & rs13297268 & A & GWAS & $45 / 1,000$ & $0.133 / 0.042$ & $3.51(1.84-6.69)$ & $5.23 \times 10^{-5}$ & $251 / 1,000$ & $0.036 / 0.042$ & $0.85(0.50-1.42)$ & 0.531 \\
\hline & & & & Replication & $48 / 3,553$ & $0.083 / 0.059$ & $1.46(0.70-3.02)$ & 0.312 & & & & \\
\hline & & & & Combined & $93 / 4,553$ & $0.108 / 0.055$ & $2.07(1.29-3.31)$ & 0.002 & & & & \\
\hline \multirow[t]{3}{*}{ CXCL12 } & 10 & rs800314 & G & GWAS & $45 / 1,000$ & $0.189 / 0.077$ & $2.89(1.66-5.03)$ & $9.12 \times 10^{-5}$ & $251 / 1,000$ & $0.094 / 0.077$ & $1.26(0.89-1.77)$ & 0.191 \\
\hline & & & & Replication & $186 / 3,553$ & $0.104 / 0.091$ & $1.16(0.82-1.65)$ & 0.407 & & & & \\
\hline & & & & Combined & $231 / 4,553$ & $0.122 / 0.088$ & $1.44(1.07-1.93)$ & 0.014 & & & & \\
\hline \multirow[t]{3}{*}{$C 1 R L$} & 12 & rs11613834 & A & GWAS & $45 / 1,000$ & $0.122 / 0.029$ & $4.75(2.40-9.40)$ & $9.47 \times 10^{-7}$ & $251 / 1,000$ & $0.038 / 0.029$ & $1.34(0.79-2.28)$ & 0.275 \\
\hline & & & & Replication & $48 / 3,553$ & $0.042 / 0.031$ & $1.36(0.49-3.72)$ & 0.554 & & & & \\
\hline & & & & Combined & $93 / 4,553$ & $0.081 / 0.031$ & $2.79(1.62-4.79)$ & $1.08 \times 10^{-4}$ & & & & \\
\hline \multirow[t]{3}{*}{ KLRD1 } & 12 & rs2270238 & $\mathrm{T}$ & GWAS & $45 / 1,000$ & $0.589 / 0.371$ & $2.42(1.58-3.72)$ & $3.26 \times 10^{-5}$ & $251 / 1,000$ & $0.378 / 0.371$ & $1.03(0.84-1.26)$ & 0.772 \\
\hline & & & & Replication & $48 / 3,553$ & $0.351 / 0.368$ & $0.93(0.61-1.42)$ & 0.737 & & & & \\
\hline & & & & Combined & $93 / 4,553$ & $0.467 / 0.369$ & $1.50(1.12-2.01)$ & 0.006 & & & & \\
\hline \multirow[t]{3}{*}{ FAM174B } & 15 & rs 8033443 & $\mathrm{~T}$ & GWAS & $45 / 1,000$ & $0.367 / 0.173$ & $2.78(1.78-4.33)$ & $2.85 \times 10^{-6}$ & $251 / 1,000$ & $0.185 / 0.173$ & $1.09(0.85-1.41)$ & 0.501 \\
\hline & & & & Replication & $48 / 3,553$ & $0.167 / 0.193$ & $0.84(0.49-1.43)$ & 0.513 & & & & \\
\hline & & & & Combined & $93 / 4,553$ & $0.263 / 0.189$ & $1.54(1.11-2.14)$ & 0.010 & & & & \\
\hline \multirow{2}{*}{$D Y N L R B 2$} & & & & Replication & $48 / 3,553$ & $0.135 / 0.117$ & $1.18(0.66-2.14)$ & 0.573 & & & & \\
\hline & & & & Combined & $93 / 4,553$ & $0.199 / 0.114$ & $1.92(1.34-2.77)$ & $3.61 \times 10^{-4}$ & & & & \\
\hline HS3ST4 & 16 & rs 3112543 & G & GWAS & $45 / 1,000$ & $0.267 / 0.110$ & $3.08(1.89-5.03)$ & $2.20 \times 10^{-6}$ & $251 / 1,000$ & $0.108 / 0.110$ & $1.02(0.74-1.40)$ & 0.893 \\
\hline
\end{tabular}




\begin{tabular}{|c|c|c|c|c|c|c|c|c|c|c|c|c|}
\hline & & & & $\begin{array}{l}\text { Replication } \\
\text { Combined }\end{array}$ & $\begin{array}{l}48 / 3,553 \\
93 / 4,553\end{array}$ & $\begin{array}{l}0.021 / 0.013 \\
0.054 / 0.012\end{array}$ & $\begin{array}{l}1.64(0.40-6.76) \\
4.60(2.37-8.95)\end{array}$ & $\begin{array}{c}0.489 \\
7.38 \times 10^{-7}\end{array}$ & & & & \\
\hline$M A F B$ & 20 & rs6029245 & $\mathrm{C}$ & $\begin{array}{l}\text { GWAS } \\
\text { Replication } \\
\text { Combined }\end{array}$ & $\begin{array}{l}45 / 1,000 \\
48 / 3,553 \\
93 / 4,553\end{array}$ & $\begin{array}{l}0.133 / 0.032 \\
0.022 / 0.035 \\
0.078 / 0.035\end{array}$ & $\begin{array}{l}4.65(2.41-8.97) \\
0.62(0.15-2.55) \\
2.36(1.35-4.12)\end{array}$ & $\begin{array}{c}5.18 \times 10^{-7} \\
0.506 \\
0.002\end{array}$ & $251 / 1,000$ & $0.042 / 0.032$ & $1.32(0.80-2.18)$ & 0.279 \\
\hline ZBED4 & 22 & rs2295407 & A & $\begin{array}{l}\text { GWAS } \\
\text { Replication } \\
\text { Combined }\end{array}$ & $\begin{array}{l}45 / 1,000 \\
48 / 3,553 \\
93 / 4,553\end{array}$ & $\begin{array}{l}0.144 / 0.038 \\
0.052 / 0.053 \\
0.097 / 0.050\end{array}$ & $\begin{array}{l}4.33(2.31-8.15) \\
0.98(0.40-2.42) \\
2.05(1.25-3.36)\end{array}$ & $\begin{array}{c}7.74 \times 10^{-7} \\
0.962 \\
0.004\end{array}$ & $251 / 1,000$ & $0.040 / 0.038$ & $1.07(0.64-1.76)$ & 0.806 \\
\hline
\end{tabular}


Supplementary Table 3. Age-stratified association results of LEF1 (rs4365796; risk allele: T) in Korean KD

\begin{tabular}{|c|c|c|c|c|c|c|c|c|c|}
\hline Locus & Chr & SNP & Risk allele & Collection & Age group & $\begin{array}{c}\text { No. } \\
\text { (case/control) }\end{array}$ & $\begin{array}{c}\text { RAF } \\
\text { (case/control) }\end{array}$ & OR $(95 \% \mathrm{CI})$ & p-value \\
\hline \multirow[t]{9}{*}{$L E F 1$} & 4 & rs4365796 & A & Combined & All KD & $1,669 / 4,553$ & $0.030 / 0.023$ & $1.29(1.01-1.64)$ & 0.042 \\
\hline & & & & & $\mathrm{KD} \leq 0.5 \mathrm{y}$ & $118 / 4,553$ & $0.068 / 0.023$ & $3.07(1.81-5.19)$ & $1.10 \times 10^{-5}$ \\
\hline & & & & & $\mathrm{KD} 0.5$ to $\leq 1 \mathrm{y}$ & $225 / 4,553$ & $0.020 / 0.023$ & $0.87(0.44-1.70)$ & 0.681 \\
\hline & & & & & $\mathrm{KD} 0$ to $\leq 1 \mathrm{y}$ & $343 / 4,553$ & $0.037 / 0.023$ & $1.60(1.05-2.45)$ & 0.027 \\
\hline & & & & & $\mathrm{KD} 1$ to $\leq 2 \mathrm{y}$ & $335 / 4,553$ & $0.020 / 0.023$ & $0.84(0.48-1.49)$ & 0.558 \\
\hline & & & & & $\mathrm{KD} 2$ to $\leq 3 \mathrm{y}$ & $305 / 4,553$ & $0.035 / 0.023$ & $1.52(0.96-2.40)$ & 0.071 \\
\hline & & & & & $\mathrm{KD} 3$ to $\leq 4 \mathrm{y}$ & $266 / 4,553$ & $0.032 / 0.023$ & $1.40(0.85-2.31)$ & 0.190 \\
\hline & & & & & $\mathrm{KD} 4$ to $\leq 5 \mathrm{y}$ & $178 / 4,553$ & $0.014 / 0.023$ & $0.60(0.25-1.48)$ & 0.264 \\
\hline & & & & & $\mathrm{KD}>5 \mathrm{y}$ & $231 / 4,553$ & $0.037 / 0.023$ & $1.63(0.98-2.69)$ & 0.056 \\
\hline
\end{tabular}

KD, Kawasaki disease; Chr, chromosome; SNP, single nucleotide polymorphism; RAF, risk allele frequency; OR, odds ratio; $95 \%$ CI, $95 \%$ confidence interval. 
Supplementary Table 4. The effect of $L E F 1$ (rs4365796; risk allele: T) genotypes on clinical parameters of KD patients in KD age subgroups (either KD $\leq 0.5 \mathrm{y}$ or KD $>0.5$ y)

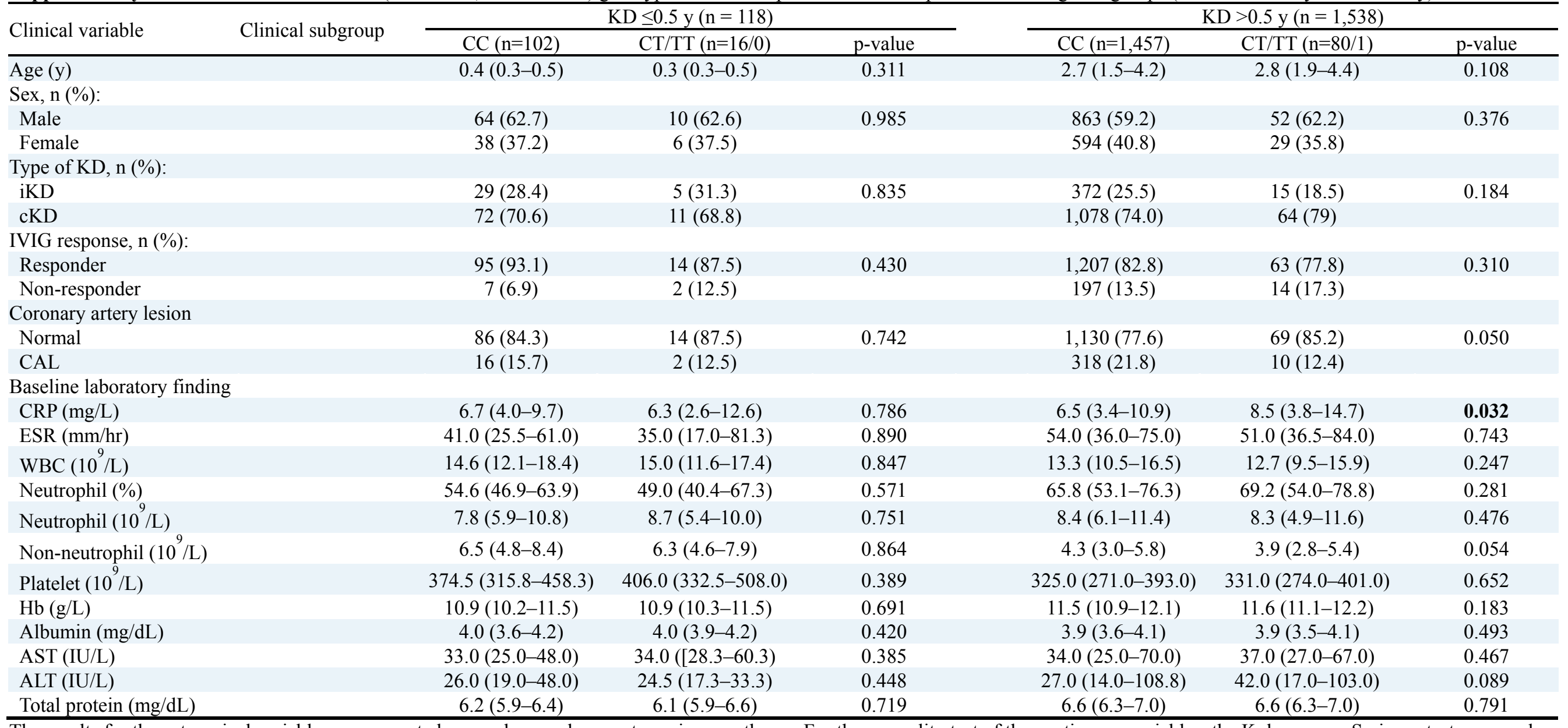

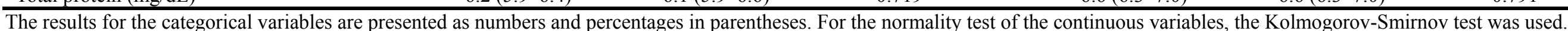

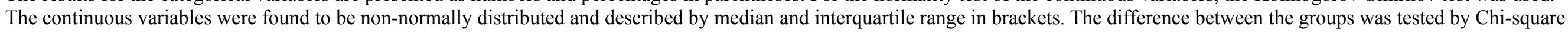
test for the categorical variables and Mann-Whitney test for the continuous variables.

A p-value of $<0.05$ was considered as statistically significant. Significant $\mathrm{p}$-values $(\mathrm{p}<0.05)$ are shown in bold.

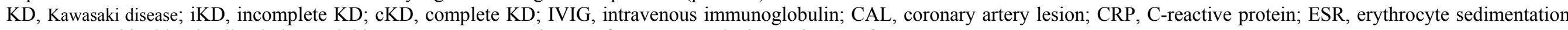
rate; WBC, white blood cell; Hb, hemoglobin; AST, aspartate aminotransferase; ALT, alanine aminotransferase. 